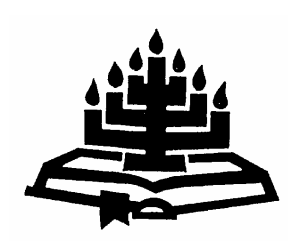

\title{
Pastorale begeleiding van die seksueel verslaafde
}

\author{
W.C. Coetzer \\ Skool vir Kerkwetenskappe \\ Potchefstroomkampus \\ Noordwes-Universiteit \\ POTCHEFSTROOM \\ E-pos: kwswcc@puk.ac.za
}

\begin{abstract}
Pastoral guidance for the sexually addicted

In this article special attention is given to a relatively new field of research with regard to sexual addiction. Sexuality is very much part of our core being. However, when this pattern becomes one of compulsion, it has the ability to unravel the person involved totally. The effects of this process within a marriage can be devastating. Attention is given to aspects like the moodaltering effect of sexual addiction, denial, rationalisation and fantasy. Focus is also placed on the cycle of addiction, the different rituals as well as the so-called "tolerance factor". Important guidelines with regard to general counselling of addicts are discussed and more specific details are given in terms of the pastoral counselling process. Unresolved past hurt and pain would seem to be of special importance and special attention is given to this aspect during the counselling process. In this way a functional pastoral foundation can be laid, thus enabling and equipping the addict to respond in a positive way with regards to further therapeutic inputs from other disciplines.
\end{abstract}

\section{Opsomming}

Pastorale begeleiding van die seksueel verslaafde

In hierdie artikel word aandag gegee aan die relatief nuwe veld van ondersoek met betrekking tot seksuele verslawing. Seksualiteit is deel van die mens se wese, maar wanneer dit ontaard in kompulsiewe gedrag, kan dit die persoon wat betrokke is totaal ontwortel. Die invloed wat so 'n proses op 'n huwelik kan hê is vernietigend. Aandag word vervolgens gegee aan die gemoedsveranderende effek van verslawing, asook die 
rol van aspekte soos ontkenning, rasionalisering en fantasering. Daar word ook gefokus op die sirkel van verslawing, die verskillende rituele, asook die sogenaamde "toleransie faktor". Belangrike riglyne met betrekking tot die algemene begeleiding van die verslaafde word bespreek en meer spesifieke riglyne word gegee ten opsigte van die pastorale beradingsproses. Onverwerkte pyn en seer vanuit die verlede blyk van besondere belang te wees en besondere aandag word aan hierdie aspek gegee tydens die voorgestelde beradingsproses. Op hierdie wyse word 'n funksionele pastorale basis gelê waardeur die verslaafde dan toegerus word om meer positief te kan reageer op verdere terapeutiese insette vanuit ander dissiplines.

\section{Inleiding}

\subsection{Die fokus van hierdie artikel}

In hierdie artikel word die volgende probleemstelling ondersoek: In watter mate kan pastorale begeleiding 'n terapeutiese rol vervul in die helingsproses van die seksueel verslaafde wat binne 'n huweliksverhouding staan? In die eerste plek word gefokus op definisies, statistieke asook die aktualiteit van die relatief nuwe studieveld van seksuele verslawing. Tweedens word aandag gegee aan sekere aanleidende oorsake, tipiese problematiese gedrag asook die siklus van verslawing. Verder word heelwat klem gelê op die praktiese begeleiding van die verslaafde.

\subsection{Basiese vertrekpunt}

As basiese epistemologiese vertrekpunt in die bespreking van hierdie tema is die gesag van die Woord van God, wat van toepassing is op elke lewensterrein, insluitende die mens se seksualiteit (vgl. De Bruyn, 1993:150). Binne die Nuwe Testament kan die Griekse term porneia in 'n sekere sin as algemene noemer dien vir heelwat van die seksuele wangedrag waaroor dit in hierdie artikel gaan (vgl. Matt. 15:19; Mark. 7:21; 1 Kor. 6:9,10; Gal. 5:19). Louw en Nida (1988:771) bespreek die term porneia onder die semantiese kategorie van seksuele wangedrag en definieer dit soos volg:

To engage in sexual immorality of any kind, often with the implication of prostitution - to engage in illicit sex, to commit fornication, sexual immorality, prostitution ... In some NT contexts porneia may refer specifically to incest. 


\section{3 'n Nuwe studieveld}

'n Redelik kontroversiële boek met die titel The Sexual Addiction, deur Patrick Carnes, het in 1983 verskyn. Die boek het nie veel aftrek gekry nie, aangesien dit op daardie stadium 'n vreemde konsep was dat gedrag, eerder as 'n substans soos drank of pille, verslawend kon wees. Die boek se titel is gevolglik verander na Out of the Shadows, en in 'n sekere sin is hiermee 'n nuwe veld gebore - veral wat betref 'n pastorale benadering tot hierdie konsep (Schneider, 2004:3). Na die verskyning van Carnes se volgende boek, Don't call it love (1991) het al meer artikels en boeke die lig gesien met dieselfde tema. In 1994 het die tydskrif Sexual Addiction and Compulsivity ontstaan en hierdeur is ' $n$ verdere stimulus aan hierdie studieveld gegee. Die afgelope tien jaar het hierdie veld dramaties gegroei, onder andere ook as gevolg van die problematiek rondom die oorweldigende aantal pornografiese webbladsye op die internet, wat daagliks toeneem. Professionele persone vanuit verskillende dissiplines is tans ook betrokke by die voorbereiding van 'n konsensus dokument met die oog daarop om seksuele verslawing in te sluit as 'n spesifieke kategorie in die vyfde uitgawe van die Diagnostic and Statistical Manual of Mental Disorders (Schneider, 2004:5). So 'n ontwikkeling sal waarskynlik ook bydra tot die formulering van diagnostiese en verwysingsprotokolle waarvolgens sielkundiges, psigiaters, mediese praktisyns, terapeute en beraders vinniger en meer effektief sodanige verslaafde pasiënte sal kan diagnoseer en behandel of verwys (Herring, 2004:39).

\subsection{Definiëring}

Seksuele verslawing word beskryf as seksuele gedrag of fantasering wat gebruik word om 'n gemoedstoestand te verander, of as 'n oorlewingsmeganisme (Parker \& Guest, 2003:14). Wildmon-White en Young (2002:263) beskryf dit as seksuele kompulsiwiteit seksuele gedrag waaroor daar min beheer is, met gevolglike spanning en onvermoë rondom sosiale funksionering. Dit gaan ook oor ' $n$ verlies van beheer in die vermoë om keuses te maak ten opsigte van jou eie seksuele gedrag. Chaney en Dew (2003:259) definieer seksuele verslawing as die onvermoë om seksuele gedrag te onderdruk ondanks negatiewe gevolge, en ook as 'n obsessie met seksuele aktiwiteite. Birchard (2004:81) se definisie lui soos volg: 
Dit is ' $n$ voortgaande patroon van seksuele gedrag met drie basiese karakteristieke: 'n onvermoë om die gedrag te beëindig, 'n voortsetting van die gedrag ten spyte van potensiële of werklike nadelige gevolge, en 'n gepreokkupeerdheid of obsessie om voort te gaan met die gedrag.

Pornografie kan soos volg gedefinieer word: Dit hou verband met 'n artikel of foto's in een of ander medium (tydskrifte, video's, TV, verhoog) wat handel oor naaktheid of seksuele aktiwiteit en waardeur seksuele gevoelens gestimuleer word (Laaser, 1996:27).

\subsection{Statistieke en aktualiteit}

Verslawing aan seks en pornografie is ' $n$ al groter wordende probleem. In 1991 is daar bereken dat tussen drie en ses miljoen mans in die VSA as seksueel verslaafdes beskryf kon word. Elf jaar later word die syfer bereken op ongeveer $6 \%$ van die VSA se bevolking (Wildmon-White \& Young, 2002:263).

Alreeds in 2002 beskryf die psigiater, William Wilson (2002:1), pornografie as 'n bedryf wat $\$ 13$ miljard (R82 miljard) per jaar genereer. Hy verwys na 900 teaters in die VSA wat reeds op daardie stadium volwasse films vertoon, asook 15000 sogenaamde volwasse winkels. Volgens hom word daar op daardie stadium reeds 100 vollengte pornografiese films per jaar vervaardig wat $\$ 500$ miljoen (R3 185 miljard) genereer.

In 'n berig wat in Rapport verskyn het, berig Tancred (2005:4) dat al hoe meer Suid-Afrikaners deesdae hulp soek vir dié "vernietigende siekte" wat mense emosioneel, liggaamlik en geldelik aftakel. In die artikel word ook gewys op verskeie groepe in die geestesgesondheidsektor wat mense deesdae met dié verslawing help. By Famsa in Kaapstad klop al hoe meer paartjies met dié probleem aan vir huweliksberading. Die outeur van hierdie artikel het saam met 'n paar ander persone deelgeneem aan die skryf van 'n artikel oor pornografie (Van Rensburg \& Swanepoel, 2003:22) wat gedurende 2003 in die Mei-uitgawe van Finesse verskyn het. Hierdie artikel het 'n oorweldigende reaksie tot gevolg gehad. Persone het van oor die hele land geskakel met versoeke om meer inligting en hulp. Tot so onlangs as Augustus 2005 is daar steeds oproepe ontvang na aanleiding van hierdie artikel. In meer as een geval was dit vroue wat gesê het dat hulle huwelik op die rotse was en dat hulle reeds in egskeidingsaksies betrokke is as gevolg van huweliksmaats wat nie kans sien om afstand te doen van pornografie nie. 
Opskrifte van artikels in koerante en tydskrifte wat die afgelope twee jaar in Suid-Afrikaanse media verskyn het, beklemtoon verder die geweldige omvang en aktualiteit van hierdie tema. Die opskrifte is onder meer die volgende: "Al meer mense erken hulle is seksverslaafdes" (Tancred, 2005:4); "Dad uses net to rape daughter" (Makgalemele, 2003:1); "Die euwel en pyn van pornografie" (Vermeulen, 2003:6); "Porno-beelde omseil gewete en die rede in kyker se brein" (Pienaar, 2003:4); "Hoekom betaal mans vir seks?" (Van Ryn, 2003:14); "Nuwe bril vir seksmisdade" (De Bruin, 2003:4); "Ek en die kinders se dinge was mooi en onskuldig" (Fitzpatrick, 2003:4); "Styging in kinderpornografie" (Versluis, 2003:4); "Seksdaad kleef lank aan die siel" (Burger, 2003:7); "My man se donker geheim” (Swanepoel \& De Lange, 2004:22).

\subsection{Onkundige beraders}

'n Aspek wat telkens in die literatuur te berde gebring word, is die onkunde by sommige beraders en terapeute met betrekking tot die kompleksiteit van hierdie probleem (Corley \& Schneider, 2002:55; Schneider, 2003:351). King (2003:197) wys op die noodsaaklikheid van 'n voortgaande opvoedingstaak in die Christelike geloofsgemeenskap. Die Christelike geloofsgemeenskap moet bewus gemaak word van die waarde van gekwalifiseerde en ervare beraders wat insig het in die probleem van seksuele verslawing.

\section{Oorsake, kenmerke en gevolge van seksuele verslawing}

\subsection{Aanleidende oorsake}

'n Agtergrond van seksuele misbruik blyk 'n groot rol te speel by seksueel verslaafdes. Carnes (soos aangehaal deur Laaser, $2003: 140$ ) het bevind dat $81 \%$ van seksueel verslaafdes seksuele trauma in die verlede beleef het; $74 \%$ het fisiese trauma beleef en $97 \%$ emosionele trauma. Hiermee saam het heel dikwels ook emosionele verwaarlosing gepaard gegaan. Wanneer 'n kind nie die nodige erkenning en bevestiging ontvang nie, lei dit maklik tot gevoelens van skaamte. Om hierin vasgevang te raak, kan lei tot verskillende vorms van verslawing (Alvarez, 2003:159). Die implikasie is dat daar 'n geweldige behoefte aan versorging en vertroeteling is, maar dat die persoon nie weet waar om dit te vind nie. Die seksuele aktiwiteit verteenwoordig in talle gevalle 'n poging om hierdie legitieme behoefte te vervul, maar op 'n illegitieme wyse (Bichard, 2004:82,85; Laaser, 2003:140). Die groot uitdaging is dus om hierdie onvervulde behoeftes en onverwerkte pyn te identifiseer 
en te hanteer (Parker \& Guest, 2003:14; Powlison, 1995:14). Chaney en Dew (2003:270) wys op die intense behoefte onder verslaafdes "om te behoort" asook die behoefte aan sosiale verbintenisse. Volgens Davies (2003:101) is 'n agtergrond van rigiditeit en seksuele skaamte (shame) oor die algemeen baie sterk aanwesig by seksueel verslaafdes.

\subsection{Problematiese gedrag}

\subsubsection{Algemene eienskappe}

Die volgende eienskappe is oor die algemeen sterk aanwesig by seksueel verslaafdes (Davies, 2003:100):

- Hulle is die slagoffers van misbruik (seksueel, fisies of emosioneel).

- Hulle kom van gesinne wat baie streng dissipline gehandhaaf het en waar daar nie intieme gebondenheid was nie.

- Hulle beskou hulself as slegte en onwaardige persone wat met skaamte oorlaai is.

- Hulle is mede-afhanklik (co-dependent) en glo dat niemand vir hulle lief sal wees soos wat hulle is nie.

- Hulle beskou seksuele aktiwiteit as die belangrikste wyse om aandag te gee aan hulle emosionele behoeftes.

- Hulle raak betrokke in 'n verskeidenheid seksuele aktiwiteite.

- Onderdrukte woede is dikwels aanwesig.

\subsubsection{Kompulsiewe seksuele gedrag}

In 'n studie waarby 94 seksueel verslaafdes betrek is, het die huweliksmaats van een derde van hierdie groep aangedui dat hulle maats se betrokkenheid by internetseks vooraf gegaan is deur jare se kompulsiewe seksuele gedrag (Schneider, 2003:346).

\subsubsection{Gemoedsversteuringe}

Bancroft en Vukadinovic (2004:225) wys op die hoë voorkoms van angsversteurings, gemoedsversteurings en versteurings ten opsigte van substansiemisbruik onder 'n groot groep selferkende seksueel verslaafdes. Heelwat hoër tellings is ook by hierdie groep gemeet ten opsigte van depressie, kompulsiwiteit en sensitiwiteit as by kontrolegroepe. Daar word ook gewys op die feit dat daar ál meer erkenning gegee word aan die resultate wat bereik word met die 
behandeling van onbeheerbare seksuele gedrag deur middel van medikasie wat die gemoedstoestand reguleer.

'n Mate van dissosiasie word ook dikwels beleef tydens seksuele gedrag (sexual acting out). Op hierdie wyse word daar in 'n sekere sin afstand verkry vanaf die realiteit van sy pyn en seer uit die verlede, en 'n gevoel van afstomping tree in. Tyd speel geen rol nie en daar vind ook depersonalisasie plaas (Chaney \& Dew, 2003:89; Bancroft \& Vukadinovic, 2004:225).

\subsubsection{Ander verslawende gedrag}

Afgesien van seksuele verslawing blyk ander verslawende gedrag ook aan die orde te wees by talle seksueel verslaafdes. Hier gaan dit veral om aspekte soos alkohol, pille, dobbel, kos, rekenaarspeletjies en koopgiere (Bancroft \& Vukadinovic, 2004:225; Schneider, 2003:331).

\subsubsection{Ontkenning en rasionalisering}

Daar is heel dikwels 'n onvermoë by verslaafdes om die effek van hul optrede ten opsigte van betekenisvolle persone in hul lewens raak te sien, en die vernietigende gevolge van hul optredes word gewoonlik gerasionaliseer - in talle gevalle was egskeidings die uiteindelike gevolg (Chaney \& Dew, 2003:268; Schneider, 2003: 335).

\subsubsection{Fantasering}

Fantasering blyk ' $n$ uiters belangrike komponent te wees in die proses van seksuele verslawing (Whitty, 2003:576; Powlison, 1995:11). Laaser (1996:25) beskryf fantasie, tesame met pornografie en masturbasie as die drie boublokke wat die basis lê vir die uiteindelike seksuele verslawing.

\subsection{Die siklus van verslawing}

Wanneer ' $n$ persoon eers een keer vasgevang is in die web van verslawing, het dit 'n verlammende invloed. In 'n onderhoud wat Powlison (1995:15) met 'n eks-verslaafde gehad het, word die proses soos volg beskryf:

Indulging in pornography is like getting a fix of cocaine or some other drug. You feel the high. When you come down you feel so awful and you say, 'I'll never do that again.' But then you want the fix. I went through that cycle a thousand times: the excitement of sin, the misery, and then the craving would come 
back. It was intoxicating powerful, because it was more than just sex.

Wanneer die siklus sy laagtepunt bereik gaan dit gepaard met selfhaat en veragting (Birchard, 2004:83).

Volgens Carnes (2001:19) beweeg die verslawingsproses deur 'n vierstapsiklus wat by elke stap in intensiteit toeneem:

- Preokkupasie - die verslaafde se denke is totaal oorweldig deur gedagtes rondom die seksuele. Hierdie tipe ingesteldheid lei tot 'n obsessiewe soeke na seksuele stimulasie.

- Ritualisering - dit gaan oor die verslaafde se eie spesiale roetines wat uiteindelik lei tot die seksuele gedrag. Die roetine intensiveer die preokkupasie en skep ook verdere seksuele opwekking en opgewondenheid.

- Kompulsiewe seksuele gedrag - dit gaan oor die werklike seksuele daad, wat die einddoelwit is van die preokkupasie en ritualisering.

- Wanhoop - die gevoel van totale hopeloosheid wat verslaafdes ervaar oor hul gedrag en hul totale magteloosheid na afloop van die seksuele aktiwiteit.

\subsection{Progressie en toleransie}

Daar is verslaafdes wat hul seksuele aktiwiteit vir 'n sekere tydperk kan opskort, maar tog sal daar wel een of ander vorm van seksuele aktiwiteit wees wat gaandeweg versleg. Dit is wat in alkoholisme die "toleransie faktor" genoem word - meer en meer word benodig ten einde die gewoonte te bevredig (Schneider, 2003:341; Laaser, 1996:44). As gevolg van hierdie toleransiefaktor en die gepaardgaande progressie in hierdie proses, kan daar volgens Carnes (2001:66) uiteindelik die volgende drie vlakke van verslawing onderskei word:

- Vlak 1: Masturbasie, kompulsiewe verhoudings, pornografie, prostitusie en anonieme seks.

- Vlak 2: Ekshibisionisme, voyeurisme, vulgêre telefoonoproepe en onsmaaklike gedrag.

- Vlak 3: Kindermolestering, bloedskande en verkragting. 


\section{Pastorale sorg aan seksueel verslaafdes}

\subsection{Belangrike riglyne vir die begeleidingsproses in die algemeen}

Corley en Schneider (2002:54) gee die volgende algemene riglyne ten opsigte van die beradingsproses aan huwelikspare:

- Dit is belangrik vir die huweliksmaat om te besef dat hy/sy nie die oorsaak is van die ander een se verslawende gedrag nie.

- Die partye moet aangemoedig word om deel te neem aan 'n formele openbaarmakingsessie wat deur die berader/terapeut gefasiliteer word. Dit sou simbolies kon dui op die begin van die opbouproses.

- Die huweliksmaat kan aangemoedig word om 'n brief te skryf aan die verslaafde waarin hy/sy al die negatiewe gevolge van hul gedrag uitspel, asook alle vrae waarop hy/sy nie antwoorde het nie. Die brief moet saamgebring word na die gesamentlike sessie.

- Die verslaafde word gevra om ook 'n brief te skryf waarin hy/sy 'n beskrywing gee van dit waarby daar 'n betrokkenheid was. Hy/sy hoef nie die fyn detail van elke daad te beskryf nie, maar wel 'n aanduiding gee van 'n gewilligheid om vrae te beantwoord.

- Dit is belangrik om die verslaafde daarop te wys dat weerhouding van belangrike inligting slegs uitloop op verdere skade ten opsigte van die verhouding.

- Aan die begin van die sessie moet albei partye hul oogmerke/doelwitte vir die sessie uitspel.

- Dit is belangrik dat daar van die kant van die verslaafde 'n belydenis sal wees ten opsigte van alle manipulerende gedrag in die verlede; ook ten opsigte van al die kere dat hy/sy voorgegee het dat die huweliksmaat die oorsaak van die probleem was. Alle vorme van oneerlikheid in die verlede moet erken en bely word.

- Die sleutel tot die sukses van hierdie proses hou gewoonlik verband met die verslaafde se vermoë om volle verantwoordelikheid vir sy/haar gedrag te aanvaar; om te erken dat die huweliksmaat die volste reg het om kwaad te wees; om te erken dat hy/sy verkeerd opgetree het en om vergifnis vra.

- Albei partye moet besef dat gevoelens van ambivalensie asook vrese vir die toekoms op hierdie stadium normaal is. 
- Dit is goed om 'n ooreenkoms aan te gaan dat geen drastiese stappe in terme van egskeidingsaksies geneem sal word binne die eerste 90 dae nie.

- Die partye moet besef dat die werklike herstel tussen twee tot vyf jaar neem.

- Binne drie tot ses maande moet die situasie weer geëvalueer word om te sien of daar vordering is.

Ten opsigte van die verslaafde doen Schneider (2003:352) die volgende stappe aan die hand:

- Die verslaafde moet aanvanklik gehelp word om deur die proses van ontkenning te breek en om die impak van sy/haar gedrag op die huweliksmaat en gesin te herken.

- Die verslawende gedrag asook die gepaardgaande leuens moet getermineer word.

- Die verslaafde moet ophou om die maat te blameer.

- Die verslaafde moet leer om probleme te hanteer op ander wyses as om te ontvlug na seksuele aktiwiteite toe.

- Strategieë om die seksuele drange te hanteer, moet in plek kom.

\subsection{Voordele van die twaalfstapprogramme}

In die navorsing rondom die probleem van seksuele verslawing is die bekende twaalf stappe van Alkoholiste Anoniem geneem en aangepas en deur twaalfstapgroepe met groot vrug toegepas in hul behandeling van seksueel verslaafdes (Carnes, 2001:170). Groepsberading hou groot voordele in met betrekking tot seksueel verslaafdes (net soos in die geval van ander vorme van verslawing). Die programme wat oor die algemeen gevolg word deur twaalfstapgroepe bied ook ' $n$ uitgebreide ondersteuningstelsel aan die verslaafde, rolmodelle vir verandering, 'n gevoel van hoop op herstel, die gevoel van om aan 'n groep te behoort en ook 'n struktuur waarbinne herstel kan plaasvind (Parker \& Guest, 2003: 21).

Die twaalf riglyne van Alkoholiste Anoniem, soos aangepas deur Carnes (2001:170), is die volgende:

1. Ons erken dat ons magteloos was ten opsigte van ons seksuele verslawing en dat ons lewens buite beheer geraak het. 
2. Ons glo dat die krag van God wat groter as onsself is, vir ons genesing kan bewerkstellig.

3. Ons maak 'n besluit om ons eie wil en ons lewens aan God se sorg toe te vertrou.

4. Ons maak 'n deurtastende en vreeslose inventaris van onsself.

5. Ons erken teenoor God, onsself en ook teenoor 'n ander persoon die presiese aard van ons oortredinge.

6. Ons is algeheel gereed om God toe te laat om hierdie foute in ons karakter te verwyder.

7. Ons vra Hom nederig om ons tekortkominge uit die weg te ruim.

8. Ons maak 'n lys van al die persone vir wie ons skade berokken het en is gewillig om teenoor almal regstellings te maak.

9. Ons stel sake reg teenoor alle sodanige persone, behalwe waar so 'n aksie tot hul nadeel of tot die nadeel van andere mag wees.

10. Ons gaan voort om persoonlik boek te hou van oortredinge, en waar ons verkeerd is, dit onmiddellik te erken.

11. Deur gebed en meditasie streef ons daarna om ons bewustelike kontak met God te verbeter. Ons bid vir kennis aangaande sy wil vir ons, asook die krag om dit uit te voer.

12. Nadat ons geestelike vernuwing beleef het op grond van hierdie stappe, probeer ons om hierdie boodskap ook aan andere deur te gee en om hierdie beginsels deurgaans toe te pas.

\subsection{Verantwoordbaarheid (accountability)}

'n Sleutelkomponent van seksuele verslawing is isolasie (Davies, 2003:105). Daar is by verslaafdes dikwels die oortuiging dat indien enigiemand hulle sou ken soos hulle werklik is, niemand vir hulle lief sal wees nie. Daarom glo hulle dat hulle nie hul behoeftes kan bevredig deur op andere te vertrou nie. Om werklik deur andere geken te word, is dus 'n bedreigende gedagte.

Verantwoordbaarheid teenoor 'n huweliksmaat of ander individu (soos 'n mentor) of teenoor 'n kleingroep kan gevolglik van besondere waarde wees tydens die herstelproses (Newheiser, 1995:46; Powlison, 1995:13). Openheid, deursigtigheid en verantwoordbaarheid is beginsels wat van deurslaggewende belang is ten opsigte van die toekomstige handhawing van 'n gesonde en gebalanseerde lewensstyl op die langtermyn. 


\subsection{Hulpmiddels rondom die probleem van seksuele verslawing}

Op die internet is daar ' $n$ aantal hulpmiddels en bedieninge wat hoofsaaklik daarop gefokus is om ondersteuning en hulp te verleen aan diegene wat vasgevang geraak het in seksuele verslawing. Alhoewel hierdie organisasies hoofsaaklik in die VSA gevestig is, is daar reeds takke gestig in talle lande reg oor die wêreld. Hulle fokus is oor die algemeen baie sterk op internetgebruikers gerig en sommige van hulle bied ook gespreksgroepe aan via die internet. Verder is daar ook 'n magdom literatuur, maandelikse nuusbriewe, tydskrifte, kassette, CD's en gemodereerde e-posondersteuningslyste. Enkele webadresse is die volgende:

- National Council On Sexual Addiction/Compulsivity: ncsac.org

- Faithful and True Ministries: faithfulandtrueministries.com

- Bethesda Workshops: bethesdaworkshops.org

- Focus on the Family: pureintimacy.org

- Sex Addicts Anonymous (SAA): www.saa-recovery.org

- Sexaholics Anonymous (SA): www.sa.org

- Sex and Love Addicts Anonymous (SLAA): www.slaafws.org

Hierdie webadresse het weer koppelings met ander soortgelyke adresse waar daar ook verskillende areas van spesialisasie is.

\subsection{Praktiese riglyne ten einde 'n terugval te verhoed}

'n Aktiewe program wat daarop gerig is om 'n terugval te verhoed, is 'n integrale deel van 'n egpaar se seksuele terapie nadat een van die twee aanvanklik seksueel verslaaf geraak het. Belangrike aspekte in hierdie verband is die volgende (McCarthy, 2002:275; Corley \& Schneider, 2002:43):

- Verslawing is 'n kroniese toestand waar daar soms 'n terugval is en verslaafdes moet leer om dit te hanteer. Die huweliksmaat moet begrip hiervoor hê en proaktief reeds 'n strategie vir selfsorg gereed hê wanneer dit gebeur.

- Na 'n terugslag moet die verslaafde so gou moontlik 'n volledige bekentenis maak. Hoe langer die detail verswyg word, hoe meer aftakelend is dit vir die vertrouensverhouding binne die huwelik. 
- Indien daar erkenning is ten opsigte van 'n terugval, moet die huweliksmaat daarteen waak om die verslaafde te wil straf vir sy/haar eerlikheid. Indien daar nie telkens straf uitgedeel word nie, sal dit lei tot 'n verhoogde eiewaarde by die verslaafde.

- Daar moet ooreengekom word dat terapiesessies ten minste een keer per maand vir die eerste aantal maande van die herstelproses gehou word - hierdie proses sou mettertyd oorgeneem kan word deur 'n ondersteuningsgroep.

- Dit is belangrik vir die betrokke partye om te besef dat jaardatums van spesifieke aangeleenthede baie traumaties kan wees. Hier gaan dit byvoorbeeld oor die datum waarop sekere pynlike inligting die eerste keer openbaar gemaak is of ontdek is. Dit kan ook jaardatums wees met betrekking tot enige ander pynlike gebeure in die verlede. Die herinneringe aan sulke gebeure presies 'n jaar later het die geneigdheid om die maat se woede opnuut te aktiveer, sowel as gevoelens van skaamte by die verslaafde.

- Daar kan op stadiums intense terugflitse wees by die huweliksmaat, asook ander posttraumatiese simptome - dit kan hierdie egpaar in 'n nuwe krisis dompel. In sulke gevalle sal die mees gepaste optrede deur die verslaafde wees om te erken dat sy/haar gedrag in die verlede verkeerd was, berou uitspreek, en ' $n$ bereidwilligheid toon om enigiets te doen wat kan bydra tot die verligting van die huidige situasie

- Die huweliksmaat moet deurgaans aangemoedig word om uitdrukking te gee aan haar pyn, sonder om te blameer.

- Dit is redelik algemeen dat een of albei partye 'n probleem kan ondervind met ander verslawings, depressie of angs. Indien dit die geval is, moet daaraan aandag gegee word. 'n Sekere vorm van depressie en angs is egter normaal binne hierdie omstandighede. Dit is daarom belangrik dat die betrokke persone sal leer om sulke emosionele toestande te hanteer eerder as wat daar gepoog word om dit deur medikasie te elimineer.

- Indien daar besluit sou word dat die huwelik onherstelbaar beskadig is, kan die pastorale begeleiding daarop gerig wees om afsluiting/afronding (closure) te bewerkstellig en ook te definieer wat die toekomstige verhouding (indien wel) tussen hulle sal wees. 


\subsection{Die beradingsproses in die besonder}

Teen die agtergrond van die bespreking tot dusver, word vervolgens 'n aantal praktiese stappe voorgestel ter begeleiding van die seksueel verslaafde (Laaser, 1996:146; Carnes, 2001:165; Coetzer, 2004:69; Wildmon-White \& Young, 2002:270; Ferree 2003:392). Hierdie proses fokus veral op die volgende vyf elemente:

- Die terminering van seksuele gedrag.

- Die terminering van rituele.

- Die terminering van fantasering.

- Die genesing van wanhoop.

- Die genesing van gevoelens van skaamte.

- Pastorale hantering van onverwerkte seer en pyn.

\subsubsection{Die terminering van seksuele gedrag}

Die boublokke van masturbasie, fantasie en pornografie moet afgetakel en ontmoedig word. Die verslaafde kan aangemoedig word om 'n "kontrak" te sluit van byvoorbeeld 90 dae waarin hy/sy onderneem om hom/haarself totaal te weerhou van seksuele aktiwiteite. Op hierdie wyse kry hy/sy die boodskap dat seks nie die heel belangrikste behoefte is nie.

Die boodskap moet ook baie duidelik gekommunikeer word dat seks nie ' $n$ metode is om negatiewe gevoelens te ontvlug nie, maar dat dit eerder 'n uitdrukking van intimiteit in die huwelik is.

\subsubsection{Terminering van die rituele}

Dit is belangrik dat die verslaafde selfinsig sal verkry met betrekking tot die rol van spesifieke rituele in die verlede wat uiteindelik gekulmineer het in die seksueel verslawende gedrag. Die aanvanklike stimulus wat telkens so 'n ritueel geaktiveer het moet geïdentifiseer word en dit moet dan pertinent vermy word.

\section{- Gesonde grense}

Die persoon moet aangemoedig word om al die tersaaklike rituele te identifiseer en asook ' $n$ lys van gesonde grense op te stel wat hy/sy voortaan wil handhaaf. Die basiese uitgangspunt moet wees: $E k$ is bereid om tot die uiterste toe te gaan ten einde te herstel! 
- Assosiasie met die regte persone

'n Lys moet gemaak word van persone wat in die verlede opbouende insette gelewer het in hierdie persoon se lewe. Daarteenoor moet ook 'n lys opgestel word van diegene wat 'n negatiewe en aftakelende invloed gehad het. Laasgenoemde persone moet voortaan vermy word.

\section{- Fisiese dissipline}

Dit is belangrik om voortaan gesonde fisiese dissipline (gesonde higiëne, gereelde oefening, versorging van die eie liggaam, ensovoorts) toe te pas, aangesien dit heel dikwels uitloop op dramatiese emosionele en geestelike verbetering in lewenskwaliteit.

\section{- Positiewe seksuele dissipline}

Daar moet voortaan gefokus word op gesonde seksuele gedrag met die lewensmaat. Dit impliseer wedersydse respek vir mekaar se liggame.

\section{- Geestelike dissipline}

Die verslaafde het dikwels vir jare lank gepoog om self in beheer te wees. Dit het egter nou tyd geword om alle beheer ten volle aan God oor te gee. Hier gaan dit onder andere ook oor die belangrikheid van kerklike betrokkenheid, asook die inskakeling by 'n geestelike ondersteuningsgroep (naas die rol wat ander kleingroepe ook veronderstel is om te vervul in die herstelproses van hierdie persoon).

\section{- Geestelike mentor}

Verslaafdes wat in die herstelproses is, moet sterk aangemoedig word om hulself te verbind aan 'n geestelike mentor.

\section{- Nuwe positiewe rituele}

Al die vroeëre negatiewe rituele moet stelselmatig vervang word met positiewe rituele waardeur die klem geplaas word op 'n gebalanseerde en gesonde lewenstyl.

\subsubsection{Die terminering van fantasering}

Hierdie is inderdaad een van die moeilikste aspekte van die herstelproses. Oor jare heen was dit die metode waardeur die verslaafde hom/haarself telkens verplaas het vanuit die pynvolle emosies en frustrasies. Daarom gaan dit voortaan moed en oefening kos om telkens die werklikheid voluit in die oë te kyk en nie 
te probeer ontvlug nie. In hierdie opsig is dit ook belangrik dat die betrokke persoon sal besef dat hy/sy keuses het.

Wanneer hy/sy begin fantaseer, is dit sinvol om hulself af te vra wat presies aan die gebeur is. Die snellers moet geïdentifiseer word wat gewoonlik die proses aktiveer. Heel dikwels sal daar dieper wortels van onverwerkte emosionele pyn uit die verlede wees wat dan hanteer sal moet word.

\subsubsection{Die genesing van wanhoop}

Persone wat vir jare in verslawing vasgevang was, worstel oor die algemeen met diep gesetelde emosionele en geestelike wanhoop. Dikwels het hulle vir hulself gesê dat indien daar 'n God is, Hy in elk geval nie omgee nie. 'n Punt van totale desperaatheid is in baie gevalle egter gelukkig bevorderlik vir 'n totale oorgawe aan God se genesende en bevrydende krag. Pastorale beraders moet gevolglik nie te gou wil wees om die wanhoop te probeer genees met oppervlakkige oplossings nie. Genesing van wanhoop word veral ook gestimuleer deur die inskakeling by 'n geestelike kleingroep. In talle gevalle vervul die ander lede van so 'n groep se getuienisse 'n terapeutiese rol in sy/haar genesingsproses. Hier leer hy/sy ook al meer selfvertroue in die hantering van rituele en fantasieë. In so 'n groep vind daar mettertyd ook selfbevestiging (self-affirmation) plaas wat as 'n sterk teenvoeter dien vir al die innerlike gevoelens van skaamte wat by tye in die verlede totaal oorweldigend was.

\subsubsection{Die genesing van skaamtegevoelens}

Talle verslaafdes worstel met 'n identiteit van skaamte wat gepaard gaan met gevoelens van totale waardeloosheid. Die diepere wortels hiervan hou dikwels verband met die agtergrond van die gesin van oorsprong en die milieu waarbinne hierdie persoon opgegroei het. Betrokkenheid by twaalfstapgroepe en ook by ander terapeutiese groepe gee aan die persoon die geleentheid om te sien hoe ander hul skaamte oor die verlede hanteer en dit help om 'n genesingsproses te stimuleer.

\subsubsection{Pastorale hantering van onverwerkte seer en pyn asook die rol van gebed}

Hierdie aspek is van deurslaggewende belang met betrekking tot die uiteindelike rehabilitering en herstel van die seksueel verslaafde. Uit die aanvanklike bespreking het geblyk dat seksuele wanpraktyke dikwels maar net ' $n$ ontvlugting is vanuit onverwerkte emosionele pyn wat by tye oorweldigend raak. Hierdie emosionele pyn hou oor 
die algemeen verband met ' $n$ innerlike emosionele vakuum wat gekoppel is aan pynvolle gebeure êrens in die verlede. Dikwels was daar 'n gebrek aan die nodige liefde, erkenning, ondersteuning of sekuriteit. Traumatiese gebeure waartydens daar geen ondersteuning of begeleiding plaasgevind het nie, en wat soms ook gepaard gegaan het met gevoelens van verwerping en vernedering, kon alles bygedra het om hierdie emosionele vakuum net wyer en dieper te maak. Seksuele dade en aksies was gevolglik slegs desperate pogings om tydelik te ontvlug vanuit die maalkolk van onverwerkte emosies.

Dit is vervolgens baie sinvol om saam met die verslaafde 'n chronologiese lys op te stel van alle traumatiese en pynlike gebeure, asook onvervulde behoeftes wat sou kon terugdateer na die vroegste kinderjare. Hierdie lys moet dan stap vir stap deurgewerk word. Pynlike herinnerings moet geverbaliseer word en emosies wat moontlik vir jare onderdruk was, moet toegelaat word om na die oppervlakte te kom. Uiteindelik moet elke insident en elke item op so 'n lys saam in gebed hanteer word. 'n Gebed om genesing van emosies en herinneringe ten opsigte van elke traumatiese en pynlike ervaring blyk telkens om genesend, helend, bevrydend en terapeuties te wees. God kan vertrou word om deur die werking van sy Heilige Gees die innerlike emosionele vakuum te vul, die storm stil te maak en weer innerlike balans te bring.

Ten slotte is dit ook belangrik vir hierdie persoon om ondanks die pyn en die teleurstellings van die verlede nogtans sy/haar waarde in Jesus Christus te besef. McGee (1998:114) verwoord hierdie aspek treffend:

We need to be honest about the pain, the anger, the disappointment, and the loneliness of our past. God has used each instance to teach me that despite my circumstances, my worth is secure in Him.

Wanneer hierdie punt bereik is, is dit vir so 'n persoon makliker om positief te reageer op verdere terapeutiese riglyne en programme, ook vanuit ander dissiplines.

\section{Samevatting en konklusie}

In hierdie artikel is aangetoon dat die probleem rondom seksuele verslawing besonder aktueel is. Met die vooruitgang van tegnologie (soos onder andere die internet) wat die probleem van seksuele verslawing nog meer kompliseer, is dit gevolglik van besondere belang dat beraders en terapeute op hoogte sal wees van die 
kompleksiteit, uitdagings en oplossings ten opsigte van hierdie probleem. Vanuit pastorale hoek is daar reeds sinvolle bydraes op navorsingsgebied gelewer en 'n groot aantal praktiese riglyne is beskikbaar vir die begeleiding van verslaafdes tot heling en bevryding - in hierdie artikel is sommige hiervan aan die orde gestel. Dit het verder ook geblyk dat emosionele pyn en seer vanuit die verlede ' $n$ besondere rol speel met betrekking tot kwesbaarheid vir seksuele verslawing. Deur pastorale gesprekvoering en gebed kan hierdie verwonde emosies hanteer word en sodoende kan 'n basis gelê word wat uiteindelik bevorderlik is vir verdere terapeutiese insette.

\section{Geraadpleegde bronne}

ALVAREZ, M.L. 2003. Issues of values: clergy and treatment. Sexual Addiction \& Compulsivity, 10:151-166.

BANCROFT, J. \& VUKADINOVIC, Z. 2004. Sexual addiction, sexual compulsivity, sexual impulsivity, or what? Toward a theoretical model. The Journal of Sex Research, 41(3):225-234.

BIRCHARD, T. 2004. "The snake and the seraph" - sexual addiction and religious behavior. Counseling Psychology Quarterly, 17(1):81-88.

BURGER, C. 2003. Seksdaad kleef lank aan die siel: 'n Mens loop nie daarvan weg soos van koffie. Beeld: 7, Apr. 15.

CARNES, P. 1992. Don't call it love. New York: Bantam Books.

CARNES, P. 2001. Out of the shadows: understanding sexual addiction. 3rd ed. Center City: Hazelden.

CHANEY, M.P. \& DEW, B.J. 2003. Online experiences of sexually compulsive men who have sex with men. Sexual Addiction \& Compulsivity, 10:259274.

COETZER, W.C. 2004. Seksualiteit. Potchefstroom. (Ongepubliseerde studiehandleiding rondom seksualiteit.)

CORLEY, M.D. \& SCHNEIDER, J.P. 2002. Disclosing secrets: guidelines for therapists working with sex addicts and co-addicts. Sexual Addiction \& Compulsivity, 9:43-67.

DAVIES, M. 2003. Clergy sexual addiction: a systemic prevention model. Sexual Addiction \& Compulsivity, 10:99-109.

DE BRUIN, P. 2003. Konsepwysigingswet vee huidige opset van tafel: nuwe bril vir seksmisdade. Beeld: 4, Aug. 1.

DE BRUYN, P.J. 1993. The ten commandments. Midrand: Varia Publishers.

FERREE, M.C. 2003. Women and the web: cybersex activity and implications. Sexual and Relationship Therapy, 18(3):385-393.

FITZPATRICK, M. 2003. "Ek en kinders se dinge was mooi en onskuldig." Beeld: 4, Aug. 3.

HERRING, B. 2004. The next 20 years: the developmental challenges facing the field of compulsive sexual behavior. Sexual Addiction \& Compulsivity, 11:35-42.

KING, S. 2003. The impact of compulsive sexual behaviors on clergy marriages: perspectives and concerns of the pastor's wife. Sexual Addiction \& Compulsivity, 10:193-199. 
LAASER, M.R. 1996. Faithful and true: sexual integrity in a fallen world. Grand Rapids: Zondervan.

LAASER, M.R. 2003. Pastors and sexual addiction. Sexual Addiction \& Compulsivity, 10:139-149.

LOUW, J.P. \& NIDA, E.A. 1988. Greek-English lexicon of the New Testament. New York: United Bible Societies.

MAKGALEMELE, T. 2003. Dad uses "net to rape daughter". Saturday Star: 1, Jun. 21.

MCCARTHY, B.W. 2002. The wife's role in facilitating recovery from male compulsive sexual behavior. Sexual Addiction \& Compulsivity, 9:275-284.

MCGEE, R.S. 1998. The search for significance. Nashville: W. Publishing Group.

NEWHEISER, J. 1995. The tenderness trap. The Journal of Biblical Counseling, 13(3):44-47.

PARKER, J. \& GUEST, D. 2003. Individualized sexual addiction treatment: a developmental perspective. Sexual Addiction \& Compulsivity, 10:13-22.

PIENAAR, A. 2003. Porno-beelde omseil gewete en die rede in kyker se brein. Beeld: 4, Okt. 3.

POWLISON, D. 1995. Slaying the Dragon. The Journal of Biblical Counseling, 13(3):11-15.

SCHNEIDER, J.P. 2003. The impact of compulsive cybersex behaviors on the family. Sexual and Relationship Therapy, 18(3):329-354.

SCHNEIDER, J.P. 2004. Sexual addiction \& compulsivity: twenty years of the field, ten years of the journal. Sexual Addiction \& Compulsivity, 11:3-5.

SWANEPOEL, M. \& DE LANGE, W. 2004. My man se donker geheim. Finesse: 22-24, Jan.

TANCRED, E. 2005. Al meer mense erken hulle is seksverslaafdes. Rapport: 4, Jun. 26.

VAN RENSBURG, R. \& SWANEPOEL, M. 2003. Naakte waarheid agter die prikkel van porno. Finesse: 22-24, Mei.

VAN RYN, N. 2003. Hoekom betaal mans vir seks? Vrouekeur: 14-15, Julie 18.

VERMEULEN, E. 2003. Die euwel en pyn van pornografie. Finesse: 6, Junie.

VERSLUIS, J. 2003. Toegang tot internet deur selfone dra by tot oortredings: styging in kinderpornografie. Beeld: 4, Jan. 26.

WHITTY, M.T. 2003. Pushing the wrong buttons: men's and women's attitude towards online and offline infidelity. Cyber Psychology \& Behavior, 6(6):569-579.

WILDMON-WHITE, M.L. \& YOUNG, J.S. 2002. Family-of-origin characteristics among women married to sexually addicted men. Sexual Addiction \& Compulsivity, 9:263-273.

WILSON, W. 2002. Pornography. (wpwilson@netpath.net) [E-pos aan:] Coetzer, W.C. (wentzel7@absamail.co.za) April 10. 


\section{Kernbegrippe:}

emosionele pyn en seer

huwelik

pastorale berading

seksuele verslawing

Key concepts:

emotional pain and hurt marriage

pastoral counselling

sexual addiction/enslavement 